\title{
İlk Dönem Hilâfet Tartışmalarında Abbâsîlerin Konum ve Tutumu (M. 632-750)*
}

\section{The Position and Attitude of Abbâsîds in the Early Caliphate Debates (A.D. 661-750)}

\author{
Mehmet Dalkılıç a,** \\ ${ }^{a}$ Doç. Dr., Kayseri Üniversitesi, İslami İlimler Fakültesi, İslam Tarihi ve Sanatları Bölümü, Siyer-i Nebi ve İslam Tarihi Anabilim Dalı, Kayseri / \\ Türkiye. \\ ORCID: 0000-0002-9844-5619
}

\section{MAKALE BİLGİSİ \\ Makale Geçmişi: \\ Başvuru tarihi: 30 Mayıs 2021 \\ Düzeltme tarihi: 15 Mayıs 2021 \\ Kabul tarihi: 20 Mayıs 2021}

\section{Anahtar Kelimeler:}

Abbâsîler

Hilâfet

Ehl-i Beyt

Emevîler

Sarı Sayfa

\section{A R T I CLE INFO}

Article history:

Received: 30 March 2021

Received in revised form: 15 May 2021

Accepted: 20 May 2021

\section{Keywords:}

Abbâsîds

Caliphate

People of the Hosue

Umayyads

Yellow Scroll
ÖZ

Abbâsîler, Abbâs bin Abdülmuttalib'in soyundan gelmektedirler. Peygamberin amcası ve ailenin en önemli ismi olan Hz. Abbâs İslam'ı kabilenin diğer üyelerine kıyasla daha geç bir dönemde kabul etmiştir. Bu durum hilâfet tartışmalarında onları geri planda bırakmıştır. Hz. Abbâs, Hz. Ali'nin halifeliği için gayret göstermiş olmakla birlikte başarılı olamamıştır. Emevîler dönenimde siyasi olaylardan uzak durmaya çalışan Abbâsîler Halife Velid bin Abdülmelik döneminden itibaren siyasi çekişmelerde taraf olmuştur. Ebu Hâşim'in vasiyeti ile iktidar mücadelesine girişen aile üyeleri gizli biçimde ihtilal hareketini başlatmışlardır. İhtilalin başarı ile sonuçlandığ 1 ana kadar gerçek niyetlerini gizlemişlerdir.. Bu çalışma Hz. Peygamberin vefatından başlayarak iktidara geliş sürecine kadar Abbâsî ailesinin hilâfet hususunda konum ve tutumlarını izah etmeyi amaçlamaktadır. Ayrıca Abbâsîlerin Emevî ve Hz. Ali soyu ile olan ilişkisini ele almaktadır.

\section{Giriş}

Hz. Peygamber'in (s.a.v.) M. 632 tarihinde Medine şehrinde vefatı İslam toplumu açısından birtakım tartışmaları beraberinde getirmiştir. Bu tartışmalar özellikle hilâfet meselesinde yoğunluk kazanmıştır. Gerek dört halife, gerekse Emevîler döneminde bu mesele İslam toplumunun gündemini meşgul etmiştir. Bu durum hilâfet eksenli tartışmalara zemin hazırlamıştır. Emevîlerin Hz. Ali soyu ve taraftarlarına karşı baskı ve şiddet politikası, ilgili tartışmaları farklı bir boyuta taşımıştır.

Emevî idarecileri tarafindan baskı altında tutulan Hz. Ali soyuna mensup kişiler ve onların taraftarları mevcut iktidarının meşruiyetini sorgulamaktan geri durmamışlardır.

\footnotetext{
*Bu çalışma, 7 Aralık 2020 tarihinde Muş Alparslan Üniversitesi İslami İlimler Fakültesinde düzenlenen İslam Düşüncesinde Eleştiri Kültürü ve Tahammül Ahlâkı II (Klasik Dönem - M. VII. - XII. Yüzyıllar) Sempozyumunda sunulan bildirinin geliştirilmiş halidir.

** Sorumlu yazar/Corresponding author
}

e-posta: mehmetdalkilic@kayseri.edu.tr 
Böyle bir durum Emevîler döneminde başarısızlıkla sonuçlanan isyan hareketlerine yol açmıştır.

Hilâfet merkezli tartışmalarda Abbâsîlerin tutumuna gelince; onlar belli bir döneme kadar arka planda kalmayı tercih etmişlerdir. Onlar Emevîler ile iyi geçinme politikasını benimsemişler ve bu duruma uygun tavırlar sergilemişlerdir. Buna rağmen kimi zaman mevcut iktidar tarafindan kendilerine şüphe ile bakıldığı da olmuştur. Bu durum onların zaman içerisinde baskı altına alınmasına yol açmıştır. Onlar yaşanan olumsuzluklara rağmen doğrudan isyan fikrini tercih etmemişlerdir. Kendilerine özgü, hilâfeti hedefleyen bir hareket başlatmışlar ve hareket sona erene kadar kendi kimliklerini gizlemeyi başarmışlardır.

Abbâsîlerin hilâfet tartışmalarında konumunu ve takındığı tutumu anlayabilmek için ilgili tarihi sürecin (M. 632-750) bir bütünlük içerisinde ele alınması ve yorumlanması gerekmektedir.

\section{Hilâfet Tartışmalarında Pasif Dönem ( M. 632- 718)}

Hz. Abbâs, kendi ismi ile anılan soyun Müslüman olarak bilinen ilk üyesidir. $\mathrm{Bu}$ aile $\mathrm{Hz}$. Peygamber'in (s.a.v.) mensup olduğu Hâşimoğulları kabilesinin bir kolunu teşkil etmekte idi. Hz. Abbâs'ın İslâm öncesi hayatı hakkında farklı rivayetler mevcuttur. Muhtemelen onun, $\mathrm{Hz}$. Peygamber'in (s.a.v.) amcası ve Abbâsi soyunun atası oluşu hakkında farklı rivayetlerin ortaya çıkmasına yol açmıştır. Onun Müslümanlar ile Müşrikler arasında yapılan Bedir savaşında Müşriklerin safında yer alması ve esir edilmiş olması en çok tartışılan hususlardan biridir. ( Taberî, 2008, II: 41-42; İbnü'l-Esîr, 1987, II: 25). Hz. Abbâs hakkında bu ve benzeri rivayetler tartışma konusu olmuştur.(Azimli, 2010-2011: 27-42). Ancak tartışma götürmez bir gerçek; onun Hz. Ali'ye nazaran çok geç İslâm'a girmiş olmasıdır. (İbn Sa'd, 2001: 19). Bu husus hilâfet tartışmalarında onun ve soyunun geri planda kalmasına yol açmıştır. Buna rağmen o, Hz. Peygamber (s.a.v.) sonrası dönemde Hâşimoğullarının yönetim işini üstlenmesini arzu ediyordu. $\mathrm{Bu}$ düşüncesini bizzat Hz. Ali'ye ileten Hz. Abbâs, ondan istediği karşılığı alamadı. (İbn Sa'd, 2001, II: 215-216; Zorlu, İslam'da İlk, 2002: 52).

$\mathrm{Hz}$. Peygamber'in vefatından kısa bir müddet sonra $\mathrm{Hz}$. Ebû Bekir halife oldu. Bu durum Hz. Abbâs'ın hoşuna gitmemiş olsa da mevcut halifeye biat etmekten kaçınmadı. Hz. Abbâs ikinci halife Hz. Ömer ile ciddi bir sorun yaşamadı. Ancak Hz. Ömer'in, vefatından önce bir komisyon vasitasıyla yeni halifenin seçilmesi düşüncesine ilk andan itibaren karşı çıktı ve Hz. Ali'yi komisyona dâhil olmaması noktasında uyardı. (Taberî, 2008, II: 580). Hz. Ali ise toplumun menfaatine olan bir işten uzak durmayacağını söyleyerek seçim komisyonuna dâhil oldu. ( Taberî, 2008, II: 580-581). Yeni halifeyi tespit amacıyla oluşturulan komisyon Hz. Osmân veya Hz. Ali'den birini seçmek için faaliyet gösterirken Ümeyyeoğulları ve taraftarlarına mensup bazı isimler aktif biçimde Hz. Osmân lehine bir tutum sergilediler.( Taberî, 2008, II: 582). Ancak Hz. Abbâs ve aile üyeleri bu süreçte Hz. Ali'yi yalnız bıraktılar. Aslında bu tavır ne ilk ne de son oldu. Özellikle Abbâsîler iktidar olma noktasında güçlerini artırdıkları sonraki dönemlerde fiili olarak Hz. Ali soyundan gelen kişi ve taraftarları yalnız bırakma şeklinde bir politika benimsediler. (Anonim, 1971: 231).
Seçim komisyonunun Hz. Osmân'1 halife seçmesi Hz. Ali kadar Hz. Abbâs ve soyu için de hayal kırıklığı oluşturdu. Ancak buna rağmen Hz. Abbâs, mevcut halifeye karşı bir tutum sergilemedi ve kendisi Hz. Osmân döneminde hayata gözlerini yumdu. (İbn Hayyât, 1995: 98) Onun vefatından sonra ailenin başına Abdullah bin Abbâs geçti. (Anonim, 1971: 25). O da tıpkı babası gibi Hz. Osmân'a karşı bir tavır içerisinde olmadı. Hz. Osmân'ın Mısır, Kûfe ve Basrâ'dan gelen isyancıların ortak kalkışması ile katledilmiş olması Abbâsîler için yeni bir dönemin başlangıcı oldu. Çünkü yeni halife Hz. Ali yönetim kadrosunu Hâşimoğulları, Ensâr ve diğer unsurlardan oluşturmaya karar verdi. (Dîneverî, ty: 133; Taberi, 2008,III: 3; İbnü'l-Esîr, 1987, III: 92; İbn Kesîr, 1998, X: 429). Bu bağlamda Abbâsî ailesine mensup birçok isim önemli yerlere yönetici olarak atand1. Ailenin lideri sayılan Abdullah bin Abbâs Hz. Ali'ye yardımcı olmak için gayret gösterdi. Özellikle problem oluşturması muhtemel konularda Hz. Ali'ye önemli tavsiyelerde bulundu. ( Taberi, 2008, III: 703-704).Gerek Cemel gerekse Siffîn savaşında Hz. Ali tarafinda yer aldı. Tahkim olayını protesto eden ayrılıkçı gurup olan Hâriciler ile Hz. Ali arasındaki görüşmeleri bizzat Abdullah bin Abbâs yürüttü. ( Anonim, 1971: 39; Taberi, 2008, III: 114). Ancak Hz. Ali'nin şehit edilmesi ve Hz. Hasan'ın kısa süren hilâfeti Abbâsîlerin siyasi etkinliğini azalttı.

M. 661 tarihinde Muâviye bin Ebî Süfyân'ın halife olması Abbâsîleri siyasi olarak pasif bir tutum sergilemeye mecbur bıraktı. Emevîlerin kurucusu ve ilk halifesi olan Muâviye bin Ebî Süfyân ile Abdullah bin Abbâs arasında geçen bir diyalog bu durumu teyit eder niteliktedir. Rivayete göre Muâviye bin Ebî Süfyân, Abdullah bin Abbâs'a: "Sen Ali’nin dini üzerine misin?" diye sordu. İbn Abbâs'ın cevabı: "Hayır! Osmân'ın da dini üzerine değilim. Fakat ben Muhammed (s.a.v.)in dini üzerineyim." oldu. (Belâzurî, 1978, III: 35). Abdullah bin Abbâs'ın bu cevabı hilâfet noktasında ortaya çıkan tartışma ve çatışmaların içerisinde yer almayacakları anlamına gelmekteydi. Abbâsîlerin en etkili isminin politik çekişmelerden uzak durma yönündeki tavrı Emevi-Abbâsî ilişkilerinde belirleyici bir rol oynadı. Bu nedenle Abbâsi ailesi Emevîler döneminde hilâfet tartışmaları ve çekişmeleri içerisinde yer almadılar. Bu durum Abdullah bin Abbâs'ın vefatına kadar devam etti. Onun ölümü sonrası ailenin başına Ali bin Abdullah geçti. (Anonim, 1971: 132-134). Emevi halifesi Abdülmelik bin Mervân ile Ali bin Abdullah arasında kısa süreli krizler yaşandı. O ısrarlı bir biçimde kendisi ve ailesinin hilâfet noktasında hak talebi olmadığını vurguladı. Tarihi kayıtlar Ali bin Abdullah'1 siyasi hırsı olmayan, kendine ibadete vermiş zahit biri olarak tasvir eder. Çok ibadet etmesinden dolayı "Seccâd" olarak anılması bu bağlamda anlamlıdır.(Anonim, 1971: 145). Ali bin Abdullah ailesini hilâfet merkezli tartışıma ve çatışmaların dışında tutmayı başardı. Ancak bu durum Velid bin Abdülmelik dönemine kadar sürdü. Rivayetler mevcut halifenin Abbâsî ailesini zor durumda bırakmak için hukuki bir hamle başlattığını haber verir. Rivayete göre Velid bin Abdülmelik, Abdullah bin Abbâs'ın cariyesinden birinin dünyaya getirdiği ve Selît olarak bilinen kişinin bizzat Abdullah'ın oğlu ve Abbâsî ailesinin doğal bir üyesi olduğunu iddia etti. Bu iddialar Emevi yönetimi ile Abbâsî ailesi arasında siyasi bir krize yol açtı. Bir müddet sonra Selît esrarengiz biçimde ortadan kayboldu. Onun cansız bedeni Ali bin Abdullah'a ait bir 
arazide bulundu. Ali bin Abdullah ve ailesi bu olay nedeniyle işkence gördü. ( Anonim, 1971: 149). Abbâsîler bir müddet sonra Halife Velid bin Abdülmelik tarafindan sürgün edildi. (Anonim, 1971: 150).

Abbâsi ailesinin sürgün edilmesi Emevî-Abbâsî ilişkilerinde yeni bir dönemin başlangıcı olmuştur. $\mathrm{O}$ zamana kadar hilâfet tartışmalarından mümkün olduğunca uzak duran, pasif bir tavır benimsemiş olan Abbâsîlerin fikirleri en son yaşanan olay ile birlikte değişti. Emevîlere karşı harekete geçmek için önce sürgünden kurtulmayı sonra da uygun zamanı kollamaya başladılar. Aradıkları firsatı Halife Süleymân bin Abdülmelik döneminde buldular. Mevcut halife Abbâsî ailesinin sürgünden dönmesine izin verdi. (Belâzurî, 1978, III: 78). Ayrıca hak ve itibarlarını onlara iade ederek istedikleri yere yerleşmeleri hususunda onlara tercih hakkı sundu. Abbâsi ailesi daha sonra Şâm bölgesinde Humeyme'ye yerleştiler. (Anonim, 1971:154).

\section{Hilâfet Tartışmalarında Yeni Dönem}

Abbâsîlerin Humeyme'ye yerleşmesi siyasi olarak yeni bir dönemin başlangıcıdır. Emevi Devleti'nin kuruluşundan Velid bin Abdülmelik dönemine kadar benimsenmiş olan tarafsızlığa dayalı pasif politikanın sürdürülebilir olmadığı yaşanan sürgün olayı ile anlaşılmış oldu. Muhammed bin Ali ve diğer aile üyeleri hilâfet tartışmalarında aktif bir politika izlemenin kaçınılmaz olduğunu fark ettiler. Ancak hilâfet tartışmalarında kendilerine hareket imkânı sağlayacak uygun bir zemin oluşturmaları gerekli idi. Diğer taraftan Emevî karşıtlarının hilâfet için Hz. Ali soyuna mensup insanlara değer vermesi onlar açısından büyük bir problem idi ve bu problem aşılması zor bir mesele olarak onların karşısında durmaktaydı.

$\mathrm{Bu}$ dönemde yaşanan bir hadise Abbâsîler için bir ümit kaynağ1 oldu. Rivayete göre Hz. Ali'nin torunu, Muhammed el-Hanefiyye'nin oğlu olan Abdullah bin Muhammed (Ebû Hâşim) dönemin halifesi Süleymân bin Abdülmelik tarafindan Şâm'a davet edildi. Kendisi Kûfe'de bulunan Hz. Ali taraftarlarının lideri idi. Daveti kabul eden Abdullah Şâm'a giderek mevcut halife ile görüştü. Ardından Kûfe'ye geri dönmek için yola çıtıtı. Ancak yolculuk esnasında şiddetli biçimde hastalandı. Kûfe'ye ulaşamayacağını anlayıp Humeyme'de bulunan Abbâsîlerin yanına gitti. Ölmeden önce lideri olduğu Kûfe teşkilatını Muhammed bin Ali'nin yönetimine biraktı. Bir müddet sonra vefat etti. (Belâzurî, 1978, III: 80). İlgili rivayette Abdullah bin Muhammed'in sadece teşkilatını değil aynı zamanda gizemli bir sayfayı teslim ettiği aktarılır. "Sarı Sayfa" olarak bilinen bu evrak Hz. Ali'den Hz. Hasan ve Hz. Hüseyin'e, o ikisinden Muhammed el-Hanefiyye'ye, ondan da oğlu Abdullah'a geçmiş idi. (Anonim, 1971: 184185) Rivayete göre Muhammed bin Ali tarafindan teslim alınan bu sayfa hilâfet tartışmalarında Abbâsîlere söz hakkı tanıyan bir içeriğe sahip gözükmekteydi. Ancak gerek Abdullah bin Muhammed'in Abbâsîlere yapmış olduğu vasiyet, gerekse Sarı Sayfa ile ilgili rivayetler problemlidir. Vasiyette 1srarlı biçimde hilâfetin Hz. Ali soyuna değil de Hz. Abbâs soyuna nasip olacağı, onların Hz. Ali soyunun intikamını alacağ1 yönündeki iddialar tartışmaya açık hususlardır. Ayrıca Sarı Sayfa'yı ön plana çıkaran Abbâsîlerin ihtilal sonrası ilgili evrakı gündeme getirmeyerek Ehl-i Beyt kavramı üzerinden meşruiyet arama girişimleri oldukça dikkat çekicidir. (Taberi, 2008,
IV: 346-347. Ehli Beyt kavramı ve bu kavram etrafındaki tartışmalar için bkz. Varol, 2013: 219-235; Eser, 2020: 738)

Abbâsîler için önemli bir figür olan Abdullah bin Muhammed'in ölümüne dair iddialar ve bu iddialar karşısında Abbâsîlerin tutumu içinde bulunmuş oldukları ikilemi göstermesi bakımından dikkat çekicidir. Şöyle ki, bazı rivayetler Abdullah'ın bizzat halife tarafindan zehirlendiğini iddia eder. Abbâsî resmi görüşünü dile getiren kaynaklara göre o, zehirlenerek değil de doğal yollarla hayatını kaybetmiştir. (Anonim, 1971: 183) Abbâsîlerin zehirlenme iddiasını reddetmesinin temel nedeni; kendileri için meşruiyet zemini teşkil eden bir hadiseyi tartışmalı hale getirmemek olabilir. Şayet zehirlenme olayı doğru olsaydı Abdullah bin Muhammed'in Muhammed bin Ali'ye vasiyet etmesi ve teşkilatını teslim etmesi planlı değil, şartların zorunlu kıldığı bir hadise olarak değerlendirilmesi kaçınılmaz olurdu. Oysa bu olay önceden planlanmış idi ve Abdullah bin Muhammed emaneti ölmeden önce kendi isteği ve iradesi ile Abbâsîlere devretmiş oldu. Tarihi rivayetlere göre bu olay M. 716 yılında gerçekleşmiştir. (Atvan, 1984: 166). Bu olaydan yaklaşık iki yıl sonra M. 718 (Taberi, 2008, IV: 66) tarihinde Muhammed bin Ali'nin girişimi ile Abbâsî hareketinin gizli olarak faaliyetlere başlamış olması anlamlıdır.

Abbâsîler, hilâfeti ele geçirme noktasında kendilerine destek olacak bir kitleye sahip değildiler. Toplumsal desteği sağlamadan başarılı olmaları da mümkün gözükmüyordu. $\mathrm{Bu}$ engeli aşma noktasında Irak bölgesinde bulunan ve $\mathrm{Hz}$. Ali soyundan gelen kişiler etrafinda toplanan halkın desteğine ihtiyaçları vardı. $\mathrm{Bu}$ sorun Abdullah bin Muhammed'in teşkilatı kendilerine devretmesi ile kısmen aşılmış oldu. Ancak bir taraftan ilgili kitlenin desteğini almak öte yandan hareket içerisinde bölünmenin önüne geçebilmek için bir slogan gerekli idi. Bizzat Muhammed bin Ali tarafından formüle edilen "Er-Rızâ min Âl-i Muhammed" (Belâzurî, 1978, III: 82; Anonim, 1971: 200) söylemi bu noktada umulandan daha büyük bir etki yaptı. Abbâsî ihtilali boyunca başta Irak bölgesi olmak üzere birçok bölgede Hz. Ali soyunu iktidarda görmek isteyen kitleler hareketin bu amaca yönelik olduğuna ikna oldular. Abbâsîler bu söylem ile bir taraftan geniş bir kitlenin desteğini alırken öte yandan ihtilal boyunca kendilerini gizlemeyi başardılar.

İhtilalin planlayıcısı olan ve bu yüzden Abbâsi ailesinde "İmâm" olarak anilan Muhammed bin Ali hareketin başlayacağ 1 yeri belirledi. Ona göre bu hareket için en uygun bölge Horasân idi. ( Belâzurî, 1978, III: 81; Anonim, 1971: 206). Bu bölge sadece Emevî başkentine uzaklığından dolayı değil aynı zamanda o dönem içinde bulunduğu sosyal ve ekonomik krizler nedeni ile tercih edildi. Memnun olmayan büyük bir kitleyi yönlendirmek ve bir amaç için harekete geçirmek daha kolay gözüküyordu. Her ne kadar hareket bu bölgede başlayacak olsa da komuta merkezi Humeyme olacaktı. Bu yüzden Horasân ile Humeyme arasında irtibatı sağlayacak bir geçiş noktasına ihtiyaç vard1. Bu bağlamda Kûfe şehri irtibat merkezi olarak seçildi. (Anonim, 1971: 190). Abbâsîler 12 kişiden oluşan üst düzey temsilci (Nakîb) seçtiler. (Anonim, 1971: 222-223; Taberi, 2008, IV: 66, Bozkurt, 2000: 41-42).Daha sonra Horasân bölgesinin değişik yerleşim merkezlerinden 
70 kişilik alt düzey temsilci (Dâî) seçildi. (Anonim, 1971: 219). Bu rakamlar bilinçli olarak tercih edildi. Özellikle Kuran ve Sünnet'e uygunluk mesajı bu şekilde vurgulanmış oldu. (Anonim, 1971: 215-216; Sharon, Black Banners, 1983: 191-192).

Abbâsi hareketi M. 718-747 yılları arasında gizli biçimde yürütüldü. Abbâsîler gerek ihtilal süreci gerekse ihtilal sonrası dönemde dini motifleri kendi çıkarları için kullanmaktan çekinmediler. Daha önce ifade ettiğimiz gibi 12 ve 70 kişilik iki farklı düzeyde yapılanma Kur'an ve Sünnet merkezli izah edilmeye başladı. Abbâsîler başlatmış oldukları ihtilal hareketini kutsal saydılar. Bir adım daha ileri giderek Bakara Sûresi 259. Ayet ile hareketleri arasında bir bağlantı kurdular. İlgili ayette yer alan 100 rakamı ve merkep (Himar) ifadesinden ilham alarak hareketin fiilen başladığı hicretin yüzüncü senesine denk düşen M. 718 yılını "Senetü'l-Hımar" olarak nitelendirdiler. Hâlbuki hareketin bu yıl başlamasının ilgili olduğu iddia edilen ayet ile hiçbir alakası yoktur. Hareketin bu yil başlamasının temel nedeni Emevî yönetiminde Ömer bin Abdülaziz'in bulunmasıdır. (Taberi, 2008, IV: 62-66). Çünkü mevcut halife güvenlikçi, sıkı tedbirlere dayalı politikadan vazgeçmiş, böylelikle Abbâsî davetçileri faaliyet göstermek için uygun bir siyasi ortama sahip olmuşlardır.

$\mathrm{Bu}$ dönemin en dikkat çekici olayı Hz. Hüseyin soyundan gelen Zeyd bin Ali ve Yahyâ bin Zeyd'in (Anonim, 1971: 230-232) başlatmış oldukları isyan hareketine Abbâsîlerin destek vermemesi başka bir ifadeyle onları yüzüstü birakmasidır. (Anonim, 1971: 231). Zeyd bin Ali'nin Kûfe'de, Yahya bin Zeyd'in Horasân bölgesinde başlatmış oldukları harekete destek verilmemesi Abbâsî İmâmı açısından bir eleştiri konusu olsa da o, bu tavrın hareketin gizliliğinin korunması açısından gerekli olduğuna inaniyordu. (Anonim, 1971: 241). Problem sadece güvenlik meselesi ile sınırlı gözükmüyordu. Şöyle ki, Abbâsîler hilâfeti ele geçirme noktasında Hz. Ali soyunun değil de Abbâs soyunun başarılı olacağını iddia ediyordu. Onlar bu görüşlerini Abdullah bin Muhammed'in Muhammed bin Ali'ye yapmış olduğu vasiyetin satır aralarında bulmakta idiler. $\mathrm{Bu}$ yüzden $\mathrm{Hz}$. Ali soyuna mensup kişilerin başlatmış olduğu isyan hareketlerinin başarısızlık ile sonuçlanması Abbâsîlerin temel iddiasını güçlendiriyordu. Aksi bir durumun bu iddiaların sorgulanmasına yol açacağında şüphe yoktu.

Abbasî hareketi M. 747-750 tarihleri arasında açık hale geldi. İhtilal, Abbâsîlerin rengini temsil eden "Gölge" ve "Bulut" isimli iki siyah sancağın açılması ile M. 747 yılında başladı. (Anonim, 1917: 276; Sharon, Revolt, 1990: 77; Daniel, 1979: 49). Hareketin açık edildiği yer; Süleymân bin Kesîr'e ait Sefizenc kasabası idi. (Anonim, 1971: 274). Gerçekte hareketi bu bölgede yöneten ve yönlendiren kişi İmâm İbrahim bin Muhammed tarafından keşfedilen ve harekete kazandırılan Ebû Müslim elHorasânî idi. (Anonim, 1971: 273-283). Abbâsîler amaçlarına ulaşmak için farklı inanç ve etnik guruplar ile işbirliği yapmada herhangi bir sakınca görmediler. Abbâsîler farklı gurupları bir amaç için başarılı biçimde organize etmeyi başardılar. Bu organizasyon siyasi ve askeri açıdan istenen güce ulaşınca batı yönünde harekete geçti. Merv, Serahs, Tûs, Nîsâbûr, Cürcân, Kûmis, Taberistân ve Hazâr, Hemedân, Nihâvend, Kum ve İsfehân başta olmak üzere önemli yerleşim birimleri Abbâsî taraftarlarının eline geçti. (Anonim, 1971: 310-338). Abbâsî ordusu Irak bölgesine ulaştı̆̆ sırada, hareketi Humeyme'de yöneten İmâm İbrahîm bin Muhammed'in kimliği ortaya çıktı. O, yakalanmadan önce Abbâsi ailesinin diğer üyelerinin Kûfe'ye gitmesine imkân sağladı. Son Emevî Halîfesi Mervân bin Muhammed askerleri vasitasıyla İmâm İbrahîm bin Muhammed'i başkent Harrân'a getirtti. (Anonim, 1971: 391). Abbâsî ailesinin diğer üyeleri güvenli biçimde Kûfe şehrine ulaştı. Şehirde bulunan ve hareketin en yetkili ismi Ebû Seleme el-Hallâl Abbâsî ailesini güvenli bir yerde sakladi. O, İmam İbrahîm bin Muhammed'in Harran'da tutuklu olduğu zindanda esrarengiz biçimde ölümü üzerine Abbâsî ailesini güvenlik problemi kalmamasına rağmen saklamaya devam etti. $\mathrm{Bu}$ süre zarfinda Hz. Ali soyundan gelen ve hayatta olan isimlere halife olmaları ve yeni kurulacak devletin başına geçmeleri için davet mektupları gönderdi. Ancak muhataplarından istediği yanıtı alamadı. (Belâzurî, 1978, III: 139). Abbâsî ailesinin saklı tutulduğu yeri bulan taraftarlar Ebu'lAbbâs'a halife olarak biat ederek Ebû Seleme'nin planlarını bozdular. M. 749 tarihinde Ebu'l-Abbâs (Abdullah bin Muhammed) Kûfe Büyük Mescidi'nde halîfe ilan edildi. (Taberi, 2008, IV: 344).

\section{Ehl-i Beyt Kurgusu Bağlamında Hilâfet Tartıșmaları}

Ebu'l-Abbâs'ın Kûfe Büyük Mescidi’nde yapmış olduğu selamlama konuşması bir teşekkür mesajının ötesinde siyasi bir anlama sahip idi. Bu bağlamda ilgili konuşmanın satır aralarını doğru olarak okumak, Abbâsîlerin hilâfet tartışmalarını sona erdirme noktasında takınmış olduğu resmi tavrı anlamak açısından önem arz etmektedir. Ebu'lAbbâs yaptığı konuşmada Abbâsî ailesinin $\mathrm{Hz}$. Peygamber'e yakınlığı üzerinde durdu. Daha sonra Kur'an-1 Kerim'de yer alan ve doğrudan veya dolaylı olarak Ehl-i Beyt'i ifade eden ayetleri okudu. Ardından şöyle seslendi: "Yüce Allah bizim faziletlerimizi insanlara bildirdi. Onlara hakkımızı vermeyi ve bizi sevmeyi gerekli kıldı. Bize ikram ve lütufta bulunarak fey ve ganimetten bolca pay ihsan etti. Allah büyük lütuf sahibidir. Sapkın olan Sebeiyye firkası riyaset, yönetim ve hilâfete bizim dışımızda olanların daha ehil olduğunu iddia etmektedir. Yüzleri kara olasıcalar! Niçin böyle olsun ey insanlar? Allah, dalalete düşmüş insanları bizim ile hidayete erdirdi. Cehaletlerinden sonra onları basiret sahibi yaptı. Helak olmuşken onları kurtardı. Hakkı bizi güçlendirirken batılı yok etti. Bizim vasıtamızla onların bozuk yönlerini düzeltti. Alçak şeyleri yükseltti, noksanlıkları tamamladı, ayrılıkları giderdi. İnsanlar birbirine düşman iken, birbirini seven, birbirine iyilik eden, dünyada yardımlaşan, ahirette koltuklar üzerinde karşılıklı oturan kişiler yaptı. Allah bunu, Hz. Muhammed'e minnet ve nimeti olarak verdi. $\mathrm{O}$, vefat edince bu iş kendisinden sonra ashabına kaldı. Onlar işlerini istişare ile yürüttüler. Ümmetin mirasını korudular, bu konuda hassas davrandılar, her şeyi gereğince yerine koydular. Yönetimi ehline verdiler ve bu işleri hakkı olan teslim ederek bitirdiler. Daha sonra Harb ve Mervanoğulları ayaklandı ve hilâfeti haksız biçimde zorla ele geçirdiler. Daha sonra da bırakmayıp birbirlerinden devraldılar. Bu hususta zulüm ettiler, hilâfeti kendilerine mal ettiler ve gerçek hak sahiplerine zulüm ettiler. Allah onlara kendisini öfkelendirene kadar mühlet verdi. Emevîler kendisini öfkelendirince, onlardan bizim vasıtamızla intikam aldı ve 
hakkımızı bize geri verdi. Ümmetimizi bize kavuşturdu. Bize yardım ederek yeryüzündeki zayıflara bizim ile lütuf ve ihsanda bulunmak için davamızı ayağa kaldırdı. Bizimle başlayıp bizimle bitirdi. Muhakkak ki ben size hayır gelen yerden zulüm, selam gelen yerden fesat gelmesini istemem. Ey Ehl-i Beyt! Bizim başarımız ancak Allah'ın yardımı iledir. Ey Kûfeliler! Siz sevgimizin mahallisiniz. Siz, bize karşı sevginizi hiç değiştirmediniz. Zâlimlerin zorlaması (bile) sizi bundan döndüremedi. Nihayet zamanımıza yetiştiniz de Allah size bizim devletimizi nasip etti. Bizim bu durumumuza en çok sevinenler, bize göre en değerli olan sizlersiniz. Maaşlarınıza yüzer dirhem zam yaptım. Hazırlıklı olup bekleyin. Ben ki, çok kan akıtan ve bunu mübah sayan kişiyim, intikam alıcı ve helak ediciyim." (Taberi, 2008, IV: 346-347. Ayrica bkz. Zorlu, Abbâsîlere Yönelik, 2001: 40-41).

Ebu'l-Abbâs'ın yaptığı konuşmada birçok husus ön plana çıkmaktadır. Öncelikli olarak o, hilâfet hakkının kendilerinden başkalarına ait olduğuna dair söylemi sert biçimde eleştirdi. Hatta bu iddiaları dile getirenleri sapkın olarak itham etti. Hiç kuş̧usuz böyle bir mesaj Hz. Ali soyu mensupları ve onların taraftarlarına yönelik idi. Onları hilâfet tartışmalarını tekrar başlatmamaları ya da benzer tartışmaların içerisinde yer almamaları noktasında bir uyarı anlamı taşımakta idi.

Ebu'l-Abbâs konuşmasında Hz. Peygamber'in (s.a.v.) vefatından sonra Emevîler dönemine kadar olan yönetimin hilâfete ehil olduğunu ve onların işlerini istişare ile yürüttüğüne dikkat çekiyordu. Oysa ailenin atası sayılan Hz. Abbâs hilâfetin Hâşimoğullarına ait bir hak olduğuna inanmaktaydı. Bu düşüncesinin bir sonucu olarak Hz. Ömer sonrası yeni bir halifenin seçilmesi noktasında istişare mekanizmasına (Şûra) ilk baştan itibaren karşı çıkmış idi. $\mathrm{Bu}$ nedenle halifenin sözleri tarihi gerçekler ile örtüşmemektedir.

Diğer taraftan Harb ve Mervan oğullarının zulmünden bahseden Ebu'l-Abbâs yapılan zulümleri genel bir kavram ile ifade etmiş̧ir. Muhtemelen o, Hz. Ali soyunun gündem olmasını ve bu bağlamda onlara avantaj sağlayacak bir mağduriyet algısının önüne geçmeye çalışmıştır.

İhtilalin başarı ile sonuçlanmasını kendilerine ait olan hakkın alınması olarak niteleyen Halife, Hz. Ali soyunun hilâfet noktasında bir hakkı olmadığını ima etmiştir. Nihayetinde Ehl-i Beyt kavramına kendilerini ifade edecek biçimde yeni bir anlam yükleyen Ebu'l-Abbâs, bu gerçeği kabul edenlere karşı cömert olacağını vaat emiştir. Diğer yandan "...size hayır gelen yerden zulüm, selamet gelen yerden de fesat gelmesini istemem.” sözüyle Kûfelileri tehdit etmekten geri durmamıştır.

\section{Sonuç}

Abbâsîlerin hilâfet tartışmalarında takınmış olduğu tutum faydacı ve çıarcı bir mahiyette olmuştur. Bu nedenle belli bir zamana kadar ilgili mesele hakkında pasif bir tutum içerisinde olan bu aile uygun şartlar neticesinde tavır değişikliğgi göstermişlerdir. Ancak bu tavır değişikliği doğrudan Emevî iktidarını hedef alan bir çizgide olmamıştır. Oysa Hz. Ali soyundan gelenler ve onların taraftarları Emevi hilâfetine karşı değişik zaman dilimlerinde başkaldırı hareketi başlatmışlardı. Abbâsîler bu isyan hareketleri karşısında "Bekle ve gör" politikası benimsemişlerdir. Diğer taraftan Hz. Ali soyunun başarılı olmasını engelleme adına onların başlattıkları isyan hareketlerine destek vermeyip onları yalnız bırakmışlardır. $\mathrm{Bu}$ hususta kendilerine eleştiri yöneltilen Abbâsi liderleri, Hz. Ali soyunun hilâfete layık olmadığını ve bu yüzden başlattıkları her isyanın başarısız olduğunu iddia etmişler ve kendi iddiaların $1 \mathrm{~Hz}$. Peygamber (s.a.v.) atfedilen bazı problemli rivayetler ile ispat etmeye çalışmışlardır. İşin ilginç tarafı Hz. Ali soyunun zulüm ve haksızlığa uğramış olması Abbâsî hareketinin çıkış noktası olmuş, Ehl-i Beyt'in intikamını alma sözü ile geniş bir kitleyi hareketlerine dâhil etmişlerdir.

M.749 yılında Ebu'l-Abbâs'ın halife olması ile birlikte hilâfet hakkına sahip olan Abbâsîler M. 750 yılında devletlerinin kurulum aşamasını tamamlamışlardır. $\mathrm{Bu}$ zamana kadar hilâfet meselesinde gerçek niyetlerini gizleme ihtiyacı hisseden Abbâsî Hanedan üyeleri asıl niyetlerini açık etmekte herhangi bir sakınca görmemişlerdir. $\mathrm{Bu}$ bağlamda; o zamana kadar Ebû Hâşim'in vasiyeti ya da Sarı Sayfa üzerinden kendilerine meşru bir alan açmak isteyenler her iki iddiadan vazgeçerek Ehl-i Beyt kavramı üzerinden iddialarını temellendirmeye çalışmışlardır.

Hilâfet hususunda geçmişte yaşanan tartışmalar Abbâsîlerin devlet kurması ile birlikte farklı bir boyuta taşınmıştır. Daha düne kadar hilâfet meselesinde Emevîleri ağır biçimde eleştiren Abbâsîler, iktidara geldikleri zaman geçmişi aratacak tutum sergilemişler ve $\mathrm{Hz}$. Ali soyuna karşı şiddetin kaynağı haline gelmişlerdir. Ebu'l-Abbâs'ın halife sıfatıyla ilk yaptığı konuşmada bu husus dile getirilmiş ve ilerleyen zamanlarda izlenecek politikaların sinyali verilmiştir. Ancak her türlü baskı ve tehdide rağmen hilâfet meselesi gündemde kalmaya devam etmiştir. $\mathrm{Bu}$ durum Ebû Cafer el-Mansûr döneminde Muhammed bin Abdullah ve İbrahim bin Abdullah isyanlarına yol açmıştır. Halife Hâdi döneminde ortaya çıkan Fah ayaklanması ya da Hârun Reşid döneminde baş gösteren Yahya bin Abdullah isyanı bu tür isyan hareketleridir.

Kısacası, zulüm ve baskıyı sona erdirme, hak ve adaleti tekrardan hâkim kılma parolası ile ihtilal hareketini başlatan Abbâsîler, ihtilal sonrası dönemde hilâfeti ellerinde tutma ve hilâfet tartışmalarına son noktayı koyma adına yeni bir Ehl-i Beyt kurgusu oluşturmuşlar ancak ilgili tartışmalara bir türlü engel olamamışlardır. Bu durum yeni bir şiddet sarmalını beraberinde getirmiştir. Hoşgörü ve tahammül iklimini tamamen tahrip eden bu anlayış İslam toplumun birçok açıdan yıpratmıştır. Tıpkı Emevîler gibi hilâfet tartışmalarında şiddet yolunu benimseyenler, toplumsal ayrışmaya zemin hazırlamışlar ve onlar bu kısır döngüden bir türlü kurtulamamışlardır.

\section{Kaynakça}

Anonim, (1971). Ahbâru'd-Devleti'l-Abbâsiyye, Beyrût: Dâru Sadr.

Atvan, H. (1984). ed-Da'vetü'l-Abbâsiyye: Tarih ve Tetavvur, Beyrût: Dârü'l-Cîl.

Azimli, M. "Siyer Yazıcıllı̆ında Abbâs Portresinin Oluşumunda Abbâsîlerin Etkisi" Yalova Sosyal Bilimler Dergisi" I, 2010-2011: 27-42. 
Belâzurî, Ebu'l-Abbâs Ahmed bin Yahyâ. (1978). Ensâbu'l-Eşrâf (thk: Abdülaziz ed-Dûrî), III. cilt, Wiesbaden: Franz Steiner Verlag.

Bozkurt, N., (2000) Oluşum Sürecinde Abbasî Ihtilali, Ankara: Ankara Okulu.

Daniel, E. L. (1979). Khurasan Under Abbâsîd Rule: 747820. Minneapolis: Bibliotheca Islamica.

Dîneverî, Ebû Hanîfe Ahmed bin Dâvûd (ty.). ed-, Ahbâru't-Tıvâl, Beyrut: Dâru'l-Kalem.

Eser, M. “Abbâsiler Döneminin İlk Mehdisi Muhammed b. Abdullah ve Onun Mehdiliği ile Ilgili Rivayetlerin Değerlendirilmesi" Bilimname: Düşünce Platformu, S. 41, 2020: 7-38.

İbn Hayyât, Halife. (1995). Târih. Beyrût: Dârü'l-Kütübi'lİmiyye.

İbn Kesîr, Ebu'l-Fida İsmail b. Ömer (1998). el-Bidâye ve'n-Nihâye, c. I-XXIV, Beyrut: Hicr.

İbn Sa‘d, Muhammed.(2001). Kitâbu't-Tabakât'i-Kebir. c. I-XI, Kahire: Mektebetü'l-Hancî.
İbnü'l-Esir, Ebu'l-Hasan Ali bin Ebi'l-Kerem. (1987). elKâmil fi't-Târih. c. I-XI, Beyrut: Dâru'l-Kütübi'lİlmiyye.

Sharon, M. (1983). Black Banners from The East. Jerussalem: Magnes Press.

Sharon, M. (1990) Revolt: The Social and Military Aspects of The Abbâsîd Revolution. Jerussalem: The Max Schloessinger Memorial Fund.

Taberî, Ebu Ca'fer Muhammed bin Cerîr.(2008). Târîhu'lUmem ve'l-Mülûk, c. I-VI, Beyrût: Dâru'l-Kütübi'lİlmiyye.

Varol, Mehmet Bahaüddin, "Toplumsal Barış Ekseninde Ehli Beyt (Anlam-Önem-Etki) Uluslararası Dini Araştırmalar ve Küresel Barış Sempozyumu, c. I, 2013: 219-235.

Zorlu, C.(2001). Abbâsîlere Yönelik Dini ve Siyasi İsyanlar. Ankara: Ankara Okulu.

Zorlu, C. (2002).İslam'da İlk iktidar Mücadelesi. Konya: Yediveren Kitap. 


\section{Extended Abstract}

The political events that took place after the death of the Prophet (pbuh) led to discussions on the caliphate. Abbâsîds perferred to remain silent for a long time in the caliphate debates. They tried to make Hz. Ali the caliph. When Hz. Ali became caliph, Ibn Abbas advised him. When Hz. Ali was martyred, Hz. Hasan became new caliph. However, he transferred his Caliphate rightes to Muawiyah ibn Abi Sufyan. Thus, the Umayyad state was established. Abbâsîd family tried to stay away from political events during Umayyad period. Therefore, there was no serious crisis between Umayyad Caliphs anda Abbâsîd family members. However, during Umayyad Caliph Walid ibn Abdalmalik peridod, good relation turned into a crisis. Umayyad Caliph wanted to suppressed Abbâsîds by using the person named Salit as an excuse. As a result, Caliph Walid exiled Ali ibn Abdallah and his family. Suleiman ibn Abdalmalik allowed the return of the Abbâsîd family,which had been in exile for a while. Abbâsîd family who settled in Humaymah continued their passive attitude towars the caliphate issue. However, after a while, there was an event that would change all balances. According to the legend, Abu Hashim (Abdallah ibn Muhammed al-Hanafiyya) came to Humaymah and made a will that left the rights of the caliphate to the Abbâsîd family before he died. He also handed them a Yellow Scroll.

Abbâsîds saw the related testament and Yellow Scroll as a sign of their power. Muhammad ibn Ali, who was running the family's business, entered in to a secret structuring. Later, he secretly started the revolutionary movement targeting Umayyads in 718. Abbâsîd revolution was ruled by Humaymah for more than thirty years. The contact point was. city of Kufah. The activities were taking place in Khurasan.

Abbâsîds did not only struggle with Umayyads during the revolution. Another rival of them was lineage of Ali. However, they need their support until the revolution was over. This situation was a big dilemma for Abbaisds. Muhammad ibn Ali came up with a formula to overcome this dilemma. The formula was a slogan, on behalf of the person who was consented from Muhammed family. (arRida min Âl Muhammad). With this slogan, the support of a large mass would be gained and everyone would think that the struggle was for the line of Ali until the revolution was over. Thus, they managed to hide their true purpose in the revolutionary process. However, they tried to create a negative perception about $\mathrm{Hz}$. Ali lineage. They determined a strategy to strengthen this perception. In this context, they did not help Zayd ibn Ali and Yahya ibn Zayd. They left them at the mercy of the Umayyads. After each failed rebellion, they aimed to create a question mark in people's minds about lineage of Ali. They continued this attitude until the revolution was over.

When the revolution was succesful, Abbâsîds saw no harm in explaining their true intentions at the point of caliphate. Abbâsîds, who previously highlighted the will of Abu Hashim and Yellow Scroll, abandoned these attitudes. Presumably they needed a stronger argument for their power. The acceptance of Ali and his descendants as members of People of the House (Ahl-i Bayt) was a big problem for their own caliphate. Redefining the related concept has become neccesary for them to solve this problem.

It was no coincidence that Abu'l-Abbas (Abdullah ibn Muhammad), the first Abbâsîd Caliph, raised this issue in his first speech. The first Abbâsîd Caliph made a new definition of People of the House (Ahl-i Bayt) by reading some verses from Quran. Abu'l-Abbas, who declared Abbâsîds to be the true People of the House (Ahl-i Bayt), disappointed Kufian People. Because they hoped one of People of the House (Ahl-i Bayt) would become the caliph. Abu'l-Abbâs promised to be generous to those who supported their power. On the other hand, he accused those who disapproved of their power of being heretics and did not refrain threatening them.

The passive attitude of Abbâsîds in the early Caliphate debates was due to the legitimacy problem. This problem was related to Abbas' becoming a late Muslim. However, Ali had become a Muslim long before. The line of Ali was more advantageous than them at the point of caliphate. This fact kept them in the background in the caliphate debates. Such a position was not a choice but an obligation for them. Abbâsîds, who took part in the debates of the Caliphate with will of Abu Hashim, came to power with an new People of the House (Ahl-i Bayt) fiction. However, this situtation did not put end to the Caliphate debates, on the contrary, it prepared the ground for new debates and Abbâsîd could not get rid of this vicious circle. 